PONTIFÍCIA UNIVERSIDADE CATÓLICA dO RIO dE JANEIRO

\title{
Motivação Empreendedora da Geração Y
}

Paula Soares de Melo Silveira

Trabalho de Conclusão de Curso

Centro de CIÊnCIAS SOCIAIS - CCS

Departamento de AdMINISTRAÇÃo

Graduação em Administração de Empresas 
Paula Soares de Melo Silveira

Motivação Empreendedora da Geração Y

Trabalho de Conclusão de Curso

Trabalho de Conclusão de Curso, apresentado ao programa de graduação em Administração da PUC-Rio como requisito parcial para a obtenção do titulo de graduação em Administração.

Orientadora: Patricia Itala Ferreira

Rio de Janeiro

Junho de 2018. 


\section{Resumo}

Soares de Melo Silveira, Paula. Motivação Empreendedora da Geração Y. Rio de Janeiro, 2018. 43 p. Trabalho de Conclusão de Curso - Departamento de Administração. Pontifícia Universidade Católica do Rio de Janeiro.

O empreendedorismo está cada vez mais presente entre os jovens dos dias de hoje. Pode-se afirmar que a Geração $Y$ é das que mais tem optado por sair de organizações para abrir a própria empresa. Rompendo paradigmas, estes jovens buscam sempre experimentar coisas novas, estão dispostos a se arriscar e ir atrás de sua realização pessoal. Dessa forma, o presente estudo buscou compreender o que motiva estes jovens a abrirem a própria empresa. Para melhor compreender essa motivação empreendedora foi realizada uma pesquisa, por meio de entrevistas, com jovens empreendedores do Estado do Rio de Janeiro que já possuem o próprio negócio.

Palavras- chave: Geração Y; Empreendedorismo; Motivação Empreendedora

\section{Abstract}

Soares de Melo Silveira, Paula. The Entrepreneurial Motivation of Generation Y. Rio de Janeiro, 2018. 43 p. Trabalho de Conclusão de Curso - Departamento de Administração. Pontifícia Universidade Católica do Rio de Janeiro.

Now days the entrepreneurship is more present among the young people. It can be said that the Generation $Y$, among all, is the one that has chosen to leave formal organizations in order to open their own company. Breaking paradigms, these young people seek to have new experiences, are willing to take risks and go after their personal fulfillment. Therefore, the present study intend to understand what motivates these young population to open their own company. To better comprehend this entrepreneurship motivation, a survey was conducted, through interviews with young entrepreneurs, from the state of Rio de Janeiro who already owns their business.

Key-words: Generation Y; Entrepreneurship, Entrepreneurial Motivation 


\section{Sumário}

1 O tema e o problema de estudo ...................................................... 1

1.1 Introdução ao tema e ao problema de estudo .................................. 1

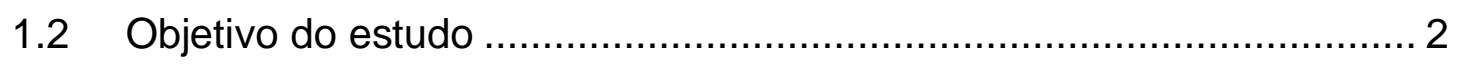

1.3 Objetivos intermediários do estudo ............................................ 2

1.4 Delimitação e foco do estudo .................................................. 2

1.5 Justificativa e relevância do estudo ................................................. 3

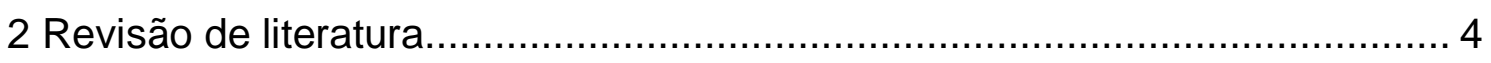

2.1 Empreendedorismo ................................................................... 4

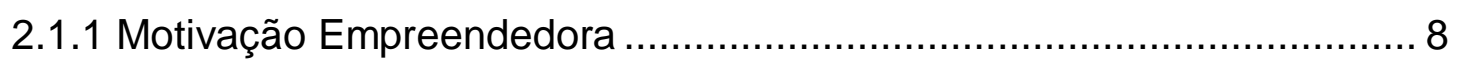

2.2 Geração Y ........................................................................... 11

2.2.1 A Geração Y e o Empreendedorismo ........................................... 13

3 Métodos e procedimentos de coleta e de análise de dados do estudo .......... 15

3.1 Método de pesquisa utilizado................................................... 15

3.2 Fontes de informação selecionadas para coleta de dados no estudo..... 16

3.3 Procedimentos e instrumentos da coleta de dados utilizados no estudo 16

3.4 Formas de tratamento e análise dos dados coletados para o estudo ..... 17

3.5 Limitações do Estudo ................................................................... 17

4 Apresentação e análise dos resultados ................................................. 19

4.1 Descrição e análise dos resultados................................................ 19

4.2 Perfil dos respondentes ............................................................. 19

4.3 Geração Y e Empreendedorismo ................................................ 21

5 Conclusões e recomendações para novos estudos ................................. 31

5.1 Sugestões e recomendações para novos estudos.............................. 32

6 Referências Bibliográficas .......................................................... 33

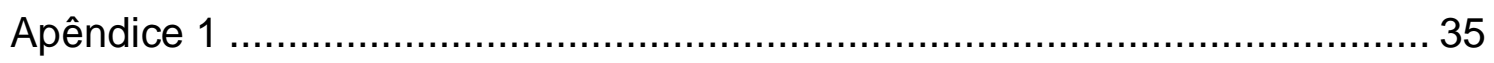




\section{Lista de Tabelas}

Tabela 1: Comparação entre gerentes tradicionais e empreendedores ......................... 5

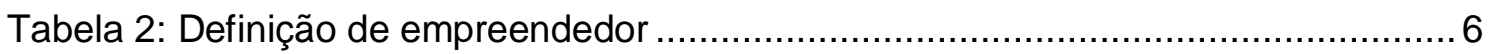

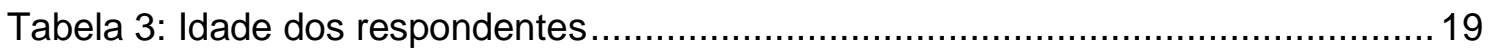

Tabela 4: Curso de graduação dos respondentes ........................................................ 20

Tabela 5: Fatores que a empresa ideal deve proporcionar ....................................... 22

Tabela 6: Características da Geração Y ............................................................ 23

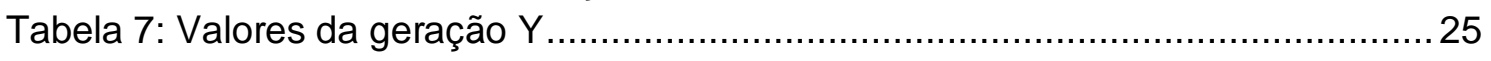

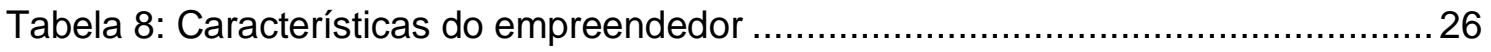




\section{0 tema e o problema de estudo}

Atualmente, o mercado empreendedor é composto por pessoas de diversas gerações. A geração $\mathrm{Y}$, a qual cresceu frente a grandes avanços tecnológicos, tem cada vez mais apresentado a vontade de empreender e abrir o seu próprio negócio. Segundo uma pequisa feita no final de 2016 pela Federação das Indústrias do Estado do Rio de Janeiro (FIRJAN), dois em cada três jovens brasileiros querem se tornar empreendedores. O presente trabalho buscou entender o que tem influenciado os jovens desta geração a abrirem o seu próprio negócio.

\subsection{Introdução ao tema e ao problema de estudo}

O empreendedorismo vem crescendo muito entre os jovens nos dias de hoje. A decisão pela abertura da uma nova empresa vem sendo cada vez uma opção como forma de fugir das organizações tradicionais e de busca por realização pessoal. Segundo Oliveira (2010) esses jovens estão determinados a modificar profundamente as premissas e paradigmas já estabelecidos.

Oliveira (2010, p. 107) afirma que "Experimentar é um próposito bem comum na Geração Y. Mesmo os jovens mais tímidos e reservados gostam da ideia de participar de coisas novas e diferentes". Isso nos permite compreender um pouco melhor o porquê do empreender ser tão presente da vida deles, desde os que vendem doces na faculdade até os que de fato tem o próprio negócio de forma mais estruturada, uma vez que os $Y$ estão sempre dispostos a tentar algo novo e diferente.

Outro tema amplamente abordado diz respeito ao empreendedorismo e à motivação empreendedora da Geração Y. Salim et al. (2004) afirma que a decisão de abrir a própria empresa é muitas vezes estimulada por fatores pessoais ou circunstâncias que podem resultar na abertura do próprio negócio, e que em algum momento da vida, as pessoas começam a se perguntar como seria a própria vida se elas fossem seus próprios patrões. 
O presente estudo tratou tanto a temática de empreendedorismo como de Geração $Y$, identificando e analisando as principais motivações desses jovens para empreender, ou seja, abrir a própria empresa.

Desta forma, o presente trabalho buscou compreender o contexto em que a Geração Y está inserida, as suas principais características e valores. Objetivou também apresentar o que é o empreendedorismo e um empreendedor, sendo este aquele que possui a própria empresa, e suas principais características para, então, responder ao questionamento: O que motiva a Geração Y a abrir o próprio negócio?

\subsection{Objetivo do estudo}

O objetivo deste trabalho é compreender os principais fatores que motivam os jovens que pertencem à Geração $Y$ na cidade do Rio de Janeiro a abrirem o seu próprio negócio.

\subsection{Objetivos intermediários do estudo}

Visando o alcance do objetivo principal, também foram propostos alguns objetivos intermediários, explicados a seguir:

- Compreender as principais características e valores dos componentes da Geração Y;

- Identificar as principais características dos empreendedores;

- Aplicar uma pesquisa de campo com o público-alvo da pesquisa.

\subsection{Delimitação e foco do estudo}

O estudo foi realizado por meio de entrevistas com componentes da Geração Y. É importante destacar que não existe um consenso sobre a faixa etária desses jovens, entre os estudiosos do assunto. Desta forma, para o presente trabalho utilizou-se a classificação definida por Oliveira (2010), que envolve os nascidos entre 1980 e 1999.

Além disso, a pesquisa foi realizada apenas com jovens $Y$ que residem no Estado do Rio de Janeiro e que já tem o seu próprio negócio. É importante destacar que, embora este público seja parte integrante da Geração $Y$ empreendedora, não é representativo de todos os seus componentes. 
Por fim, a pesquisa buscou identificar as principais características desses jovens e o que os motivou a abrirem o próprio negócio.

Os empreendedores estão dispersos por diversos países do mundo, contudo, o estudo buscou retratar a motivação empreendedora na cidade do Rio de Janeiro. A pesquisa de campo foi realizada no mês de maio de 2018.

\subsection{Justificativa e relevância do estudo}

A relevância desse estudo reside no fato de que é observado um crescimento significativo nas taxas de abertura de novos empreendimentos, principalmente por jovens. Por outro lado, existem poucos estudos que busquem compreender as motivações dos jovens e os fatores que estimulam o processo empreendedor.

Os resultados desse trabalho podem contribuir para incrementar os estudos a respeito da Geração $Y$ e do empreendedorismo. Embora haja um grande número de estudos sobre o perfil do jovem $\mathrm{Y}$ e dos empreendedores, poucos estudos brasileiros associam esses dois assuntos. Dessa forma, esperase contribuir para que seja melhor entendido o que tem levado os jovens a abrirem o próprio negócio. 


\section{Revisão de literatura}

Este tópico explora os conceceitos sobre os principais itens deste trabalho, ou seja, Empreendedorismo, Geração Y e Motivação Empreendedora.

\subsection{Empreendedorismo}

A palavra empreendedor (entrepreneur) é de origem francesa e significa aquele que está disposto a assumir riscos e começar algo novo. Antes de definir o tema é importante fazer uma análise histórica do desenvolvimetno da teoria do empreendedorismo.

$\mathrm{Na}$ Idade Média, o termo empreendedorismo foi usado para definir aquele que administrava grandes projetos de produção. Eram indivíduos que não assumiam grandes riscos e apenas utilizavam os recursos disponíveis, provindos do governo, para gerirem seus projetos.

Já no século XVII, o empreendedor estabelecia um acordo contratual com o governo para realizar determinado projeto, em que qualquer lucro ou prejuízo era responsabilidade do empreendedor. Daí surgiram os primeiros sinais da relação entre assumir riscos e empreendedorismo.

No século XVIII em virtude do início da industralização que ocorria pelo mundo, o capitalista e o empreendedor foram finalmente diferenciados. O primeiro era aquele que fornecia o capital e o segundo, o que assumia riscos.

No final do século XIX e início do século $X X$, os empreendedores frequentemente eram confundidos com os gerentes ou administradores (o que ocorre até os dias de hoje), sendo analisados como aqueles que planejam, dirigem e controlam as ações desenvolvidas na organização, pagam os salários dos empregados e organizam a empresa. O movimento de empreendedores no Brasil começou a tomar forma na década de 1990, uma vez que antes disso pouco se falava sobre empreendedorismo e em criação de empresas, já que os ambientes político e econômico do país não eram oportunos (DORNELAS, 2014).

Dornelas (2014) faz uma comparação entre os gerentes tradicionais e os empreendedores, de forma a explicar as principais características tanto de um quando do outro, a qual será mostrada na Tabela 1. 
Tabela 1: Comparação entre gerentes tradicionais e empreendedores

\begin{tabular}{|c|c|c|}
\hline Temas & Gerentes Tradicionais & Empreendedores \\
\hline Motivação Principal & $\begin{array}{l}\text { Promoção e outras } \\
\text { recompensas da } \\
\text { corporação, como } \\
\text { secretária, status, poder } \\
\text { etc. }\end{array}$ & $\begin{array}{l}\text { Independência, } \\
\text { oportunidade para } \\
\text { criar algo novo, } \\
\text { ganhar dinheiro. }\end{array}$ \\
\hline Referência de tempo & $\begin{array}{c}\text { Curto prazo, } \\
\text { gerenciando } \\
\text { orçamentos semanais, } \\
\text { mensais etc. e com } \\
\text { horizonte de } \\
\text { planejamento anual. }\end{array}$ & $\begin{array}{c}\text { Sobreviver e } \\
\text { atingir cinco a dez } \\
\text { anos de } \\
\text { crescimento de } \\
\text { negócio. }\end{array}$ \\
\hline Atividade & Delega e supervisiona. & $\begin{array}{l}\text { Envolve-se } \\
\text { diretamente. }\end{array}$ \\
\hline Status & $\begin{array}{c}\text { Preocupa-se com o } \\
\text { status e como é visto na } \\
\text { empresa }\end{array}$ & $\begin{array}{l}\text { Não se preocupa } \\
\text { com o status. }\end{array}$ \\
\hline Como vê o risco & Com cautela. & $\begin{array}{l}\text { Assume riscos } \\
\text { calculados. }\end{array}$ \\
\hline Falhas e erros & $\begin{array}{c}\text { Tenta evitar erros e } \\
\text { surpresas. }\end{array}$ & $\begin{array}{l}\text { Aprende com } \\
\text { erros e falhas. }\end{array}$ \\
\hline Decisões & $\begin{array}{l}\text { Geralmente concorda } \\
\text { com seus superiores. }\end{array}$ & $\begin{array}{l}\text { Segue seus } \\
\text { sonhos para } \\
\text { tomar decisões. }\end{array}$ \\
\hline A quem serve & Aos outros (superiores). & $\begin{array}{l}\text { A si próprio e } \\
\text { seus clientes. }\end{array}$ \\
\hline Histórico familiar & $\begin{array}{l}\text { Membros da família } \\
\text { trabalharam em } \\
\text { grandes empresas. }\end{array}$ & $\begin{array}{c}\text { Membros da } \\
\text { família possuem } \\
\text { pequenas } \\
\text { empresas ou já } \\
\text { criaram algum } \\
\text { negócio. }\end{array}$ \\
\hline $\begin{array}{l}\text { Relacionamento com } \\
\text { outras pessoas }\end{array}$ & $\begin{array}{l}\text { A hierarquia é a base } \\
\text { do relacionamento. }\end{array}$ & $\begin{array}{l}\text { As transações e } \\
\text { acordos são a } \\
\text { base do } \\
\text { relacionamento. }\end{array}$ \\
\hline
\end{tabular}

Fonte: Dornelas (2005, p. 27)

Para Dornelas (2014, p.28), "Empreendedorismo é um neologismo derivado da livre tradução da palavra entrepreneurship e utilizado para designar os estudos relativos ao empreendedor, seu perfil, suas origens, seu sistema de atividades, seu universo de atuação".

São muitas as definições que podem ser encontradas a respeito do que é um empreendedor. Uma delas determina que "Empreendedor é aquele que cria um equilíbrio, encontrando uma posição clara e positiva em um ambiente de 
caos e turbulência, ou seja, identifica oportunidades na ordem presente" (KIRZNER, 1973, apud DORNELAS, 2014, p.23).

Tomei, Russo e Autonaccio (2008), por sua vez, usam dois autores para definir o que é um empreendedor, tal como detalhado na Tabela 2.

Tabela 2: Definição de empreendedor

\begin{tabular}{|c|c|c|}
\hline & Schumpeter & Carland \\
\hline Empreendedor & $\begin{array}{c}\text { É o indivíduo que realiza } \\
\text { novas combinações e as } \\
\text { mostra para o mundo na } \\
\text { forma de bens e serviços, } \\
\text { formas de organização de } \\
\text { mercado, processos de } \\
\text { produção etc. Ele identifica } \\
\text { e avalia oportunidades, e as } \\
\text { aproveita para inovar e } \\
\text { assume os riscos inerentes } \\
\text { desse negócio. É aquele } \\
\text { que destrói a ordem } \\
\text { econômica a partir de uma } \\
\text { inovação. }\end{array}$ & $\begin{array}{c}\text { É o indivíduo que cria } \\
\text { e gerencia um } \\
\text { negócio com o } \\
\text { objetivo de gerar lucro } \\
\text { e desenvolvimento. É } \\
\text { um sujeito que se } \\
\text { caracteriza } \\
\text { principalmente pela } \\
\text { necessidade de } \\
\text { realização, o } \\
\text { comportamento } \\
\text { criativo e inovador, a } \\
\text { predisposições para } \\
\text { assumir riscos e a } \\
\text { adoção de práticas de } \\
\text { gestão estratégica do } \\
\text { neqócio. }\end{array}$ \\
\hline
\end{tabular}

Fonte: Adaptado de Tomei, Russo e Autonaccio (2008)

O empreendedor - pelo que foi visto até aqui - é agente de impacto na economia e na geração de empregos e, em decorrência, diversas instituições se dedicam a melhor compreender sobre esse fenômeno. De acordo com um importante relatório de pesquisa que aborda a atividade empreendedora dos países e observa seu relacionamento com o crescimento econômico, o Global Entrepreneurship Monitor (GEM), publicado em 2016, a Taxa Total de Empreendedores (TTE) - percentual de empreendedores que tem mais de 3.5 anos de atividade - brasileiros é de $36 \%$, sendo um número inferior ao apresentado em 2015 (39,3\%) o que pode ter sido causado pelo fato de que o país vive um período de crise. Já a Taxa de Empreendedores Iniciais (TEA) percentual de empreendedores que tem no máximo 3.5 anos de atividade - em 2016 no Brasil é de 19,6\% (GEM 2016), sendo também menor do que a apresentada em 2015 de 21\% (GEM 2015). A TEA também mostra a porcentagem de taxas específicas segundo faixa etária a qual apresenta um aumento entre os jovens de 18 a 24 anos de 19,2\% em 2015 para 20,1\% em 2016, porém a taxa apresentou um decréscimo entre os jovens de 25 a 34 anos sendo de $32.8 \%$ em 2015 e 22,9\% em 2016. Além disso, a pesquisa feita pela 
GEM em 2016 também mostra que os jovens entre 18 e 34 anos são os que mais abrem empreendimentos ultimamente.

Por outro lado, no final de 2016 a Federação das Indústrias do Estado do Rio de Janeiro (FIRJAN) fez uma pesquisa com jovens entre 25 e 35 anos, pertencentes às classes $A B C$ e com pelo menos o ensino superior em andamento, na qual $68,2 \%$ dos respondentes mostraram o desejo de abrir seu próprio negócio contra $31,8 \%$ que não almejam empreender. Isso nos permite concluir que cada vez mais eles querem tornar-se empreendedores.

Dornelas (2014) também destaca que existem algumas características extras, além dos atributos do administrador, que os empreendedores necessitam possuir, como por exemplo: serem visionários, para enxergarem como será o futuro para seu negócio; saber tomar decisões na hora certa; serem indivíduos que fazem a diferença, capazes de transformar uma idéia abstrata em algo concreto; explorar ao máximo as oportunidades, pois para os empreendedores as boas ideias são aquelas que todos conseguem ver, mas não identificam a forma de transformá-las em oportunidade; serem determinados e dinâmicos, pois se comprometem com as suas ações e ultrapassam os obstáculos a fim de "fazer acontecer"; serem dedicados, pois comprometem seus relacionamentos com amigos e família para se dedicarem 100\% àquilo que buscam; serem otimistas e apaixonados pelo que fazem, em vista de demonstrarem amor pelo trabalho e isso ser seu principal combustível para suas realizações; serem independentes e construirem o próprio destino, eles querem criar algo novo e traçar seus próprios passos, além de preferirem ser independentes em vez de empregados; saberem liderar e serem formadores de equipe; serem bem relacionados, visto que um empreendedor necessita saber construir uma rede de contatos; serem organizados; saberem se planejar; possuir conhecimento, estando sempre em busca de aprender continuamente; saberem assumir e gerenciar os riscos, de forma a arriscar conscientemente.

Dornelas (2014, p. 50) também afirma que "Os empreendedores de sucesso são aqueles que estão sempre atrás de novas idéias de negócio e de verdadeiras oportunidades de mercado, atentos a tudo que ocorre à sua volta. São curiosos e questionadores e não aceitam a primeira explicação para os fatos ocorridos".

Segundo Salim et al. (2004) existem algumas etapas que constituem o processo empreendedor, que consiste na combinação adequada entre conhecimento, inovação e capacidade empreendedora. Uma dessas etapas é o 
despertar da motivação para criar seu próprio negócio, o que será detalhado na sequência.

\subsubsection{Motivação Empreendedora}

Para Ribas (2011, p.12) "Motivação empreendedora é a motivação para correr o risco de realizar uma ação de empreender associada a uma recompensa, segundo a percepção de sucesso do empreendedor".

Robbins, Judge e Sobral (2010) comentam sobre a teoria das necessidades, desenvolvida por David McClelland e sua equipe em 1961, a qual afirma existirem três necessidades importantes que explicam a motivação: a) Necessidade de realização, em que o indivíduo busca a excelência em suas realizações a fim de alcançar o sucesso; b) Necessidade de poder, que consiste na necessidade de fazer com que os outros se comportem de forma diferente daquela habitual, a fim de mostrar quem está no controle; c) Necessidade de afiliação, que é o desejo de manter uma boa relação com aqueles que o cercam, a fim de se sentir querido e aceito.

Além disso, Greatti e Senhorini (2000) identificaram dez comportamentos básicos de empreendedores apresentados por McClelland, baseados nas três necessidades desenvolvidas por ele, que serão apresentadas em três conjuntos a seguir:

\section{Conjunto de realização:}

- Busca de oportunidades e iniciativas: realiza atividades antes de solicitado ou forçado pelas circunstâncias; busca novas áreas de atuação, produtos e serviços para ampliar seu empreendimento; aproveita oportunidades fora do comum para começar um negócio novo, obter financiamentos, equipamentos, local de trabalho ou assistência.

- Persistência: age diante de dificuldades relevantes; insiste ou muda de estratégia com a finalidade de enfrentar desafios ou dificuldades; responsabiliza-se pessoalmente pelo cumprimento dos objetivos estabelecidos. Porém, deve ter a capacidade de analisar resultados e aprender com seus fracassos, evitando persistir teimosamente.

- Correr riscos calculados: analisa as alternativas e calcula riscos cuidadosamente; age para diminuir riscos ou controlar resultados; coloca- 
se em situações que implicam em desafios moderados, contanto que seja calculado, em que as chances de sucesso sejam maiores que as de fracasso e, principalmente, em que ele possa ter controle sobre os fatores que determinarão o sucesso do empreendimento.

- Exigência de qualidade e eficiência: age de forma a executar melhor as coisas, mais rapidamente ou mais barato; procede de forma a realizar coisas que satisfaçam ou excedem aos padrões de excelência; assegura que o trabalho seja terminado a tempo e atenda aos padrões de qualidade previamente combinados, já que o empreendedor geralmente se destaca pelo nível de qualidade mais alto de seus trabalhos, resultado de seus padrões de excelência e energia para trabalhar duro.

- Comprometimento: sacrifica-se pessoalmente ou depende de um grande esforço para completar uma tarefa contratada; trabalha junto com seus empregados ou os substitui caso seja necessário terminar uma tarefa; prima em manter os clientes satisfeitos e coloca em primeiro lugar a boa vontade em longo prazo, em vez de lucro em curto prazo.

\section{Conjunto de planejamento:}

- Busca de informações: pesquisa pessoalmente informações de clientes, fornecedores e concorrentes; pesquisa pessoalmente sobre como fabricar um produto ou oferecer um serviço; solicita orientação de especialistas para obter assessoria técnica ou comercial e assim fundamentar e possibilitar a elaboração de estratégias racionais, com boas chances de êxito.

- Estabelecimento de metas: fixa objetivos que lhe proporcionem desafios e que tenham significado pessoal; fixa metas em longo prazo, claras e específicas; fixa objetivos de curto prazo e mensuráveis, já que se um objetivo é escrito, há um aumento de $60 \%$ na probabilidade de atingi-lo, orientando para o futuro e para resultados.

- Planejamento e monitoramento sistemáticos: planeja um trabalho grande, dividindo-o em partes mais simples e com prazos definidos; acompanha e revisa seus planos, embasado em informações sobre o desempenho real e em novas circunstâncias; mantém registros financeiros e os utiliza para 
tomar decisões. A energia para este trabalho geralmente vem do alto padrão de excelência do empreendedor e do compromisso com os próprios objetivos. Como precisa de feedback constante, busca atividades que forneçam informações constantes e concretas sobre 0 próprio desempenho.

\section{Conjunto de poder:}

- Independência e autoconfiança: busca autonomia em relação a normas e controles de outros; mantém suas decisões, mesmo quando outras pessoas se opõem, diante de resultados desanimadores; mostra-se confiante na sua própria capacidade de completar uma tarefa difícil ou de enfrentar um desafio. Geralmente analisa as situações-problema no sentido de avaliar as fraquezas e as ameaças às suas ações, buscando formas de exercer controle para eliminá-las ou amenizá-las.

- $\quad$ Persuasão e rede de contatos: usa de estratégias para influenciar ou persuadir os outros; usa de pessoas influentes para atingir seus próprios objetivos; age para desenvolver e manter relações comerciais. Exercer controle sobre situações geralmente significa exercer influência sobre pessoas. Para realizar objetivos, é necessário negociar, fazer acordos, convencer pessoas, obter colaboração, levar pessoas a acreditarem em determinada ideia.

Outra visão a respeito das necessidades é fornecida por Carvalho e González (2006) os quais propuseram um modelo em que cinco variáveis explicam a vontade de empreender. São elas: antecedentes pessoais, conhecimentos empresariais, motivações empreendedoras, auto-eficácia empreendedora e envolvente institucional. Para o presente estudo foram levadas em consideração apenas as motivações empreendedoras, as quais estão relacionadas a quatro causas, apresentadas na sequência:

a) Necessidade de independência: pôr em prática as próprias idéias, ter mais autonomia, maior flexibilidade, tirar vantagem das tecnologias;

b) Necessidade de desenvolvimento pessoal: implementar um negócio de sucesso e inovador, realização pessoal;

c) Percepção da instrumentalidade da riqueza: ter mais rendimentos, ser rico, fugir do desemprego, maior segurança no futuro; 
d) Necessidade de aprovação: ganhar prestígio, reconhecimento, ser influente, ser mais respeitado pelos amigos e colegas, seguir o exemplo de empresários os quais admiram, dar continuidade à tradição empresarial da família.

De acordo com o Relatório GEM (2016), a motivação para empreender, abrir o próprio negócio, pode ocorrer pela necessidade - em que o indivíduo decide empreender por conta de não estar empregado em nenhuma empresa, criando assim um negócio como alternativa de renda para sua sobrevivência e de seus familiares - ou por oportunidade - que são as pessoas ligadas nas oportunidades de novos negócios e que buscam a independência como forma de sobreviver.

A pesquisa feita pela FIRJAN (2016) estabelece que as principais motivações dos jovens entre 25 e 35 anos para abrir o seu próprio negócio são: a realização de um sonho (76,4\%), a busca por qualidade de vida $(75,6 \%$, oportunidade de altos ganhos (70\%), a aposta em um mercado promissor $(66,1 \%)$, a liberdade de não ter chefes $(64,5 \%)$, a busca por respeito e reconhecimento $(63,3 \%)$, a liberdade de não ter horários fixos $(60,7 \%)$, o desejo de construir algo que faça diferença para a sociedade $(58,4 \%)$, a falta de perspectivas no mercado de trabalho formal $(41,2 \%)$ e a continuação de um negócio familiar $(31,1 \%)$. As principais características desses jovens que pertencem à Geração Y serão detalhadas na sequência.

\subsection{Geração Y}

A geração $\mathrm{Y}$, ou Geração Milênio, é marcada por uma época de grandes avanços tecnológicos. Os jovens pertencentes a essa geração são normalmente conhecidos como millenials, um termo criado por Strauss e Neil Howe em 1990. O fácil acesso à internet e a rápida adaptação às novas tecnologias moldou o seu comportamento e foram determinantes para as suas características.

Segundo Oliveira (2010), o nome dessa geração se deveu à forte influência da antiga União Soviética sobre os países que adotavam o regime comunista, onde se podia até mesmo determinar a primeira letra do nome a ser dado aos bebês. Neste período, anos 1980 e 1990, a principal letra era o Y, que mais tarde foi utilizado para determinar os nascidos daquela geração.

Além disso, não há um consenso com relação ao período que representa a Geração Y, visto que diversos autores apresentam diferentes períodos para 
determinar aqueles pertencentes a essa geração. Dessa forma, levaremos em consideração os nascidos entre 1980 e 1999 (OLIVEIRA, 2010).

Em outro estudo, Oliveira (2011) afirma que os $\mathrm{Y}$ são muito bem informados, já que cresceram junto com a internet e por isso dominam com facilidade todas as tecnologias disponíveis. São também curiosos, comunicativos, hiperativos e, na sua maioria, ambiciosos. São pessoas com segurança para arriscar e que já entram no mercado de trabalho com a intenção de criar seus próprios negócios e fazerem a diferença.

Para Oliveira (2010), esta geração possui determinados estereótipos, cujos principais são:

\begin{abstract}
Fazer questionamentos constantemente, demonstrar ansiedade e impaciência em quase todas as situações, desenvolver idéias e pensamentos com superficialidade, buscar viver com intensidade cada experiência, ser transitório e ambíguo em suas decisões e escolhas (OLIVEIRA, 2010, p. 63).
\end{abstract}

Para Lipkin e Perrymore (2010, p.2), a Geração Y é “(...) multitalentosa, superestimulada, socialmente consciente, exigente e criativa", envidenciando não somente o quanto são gananciosos, mas o desejo de fazerem a diferença e se mostrarem para o mundo. Esta geração “(...) valoriza o tempo livre, a energia e a saúde no trabalho, que deve ser parte da vida, não a própria vida" (LIPKIN; PERRYMORE, 2010, p. 3).

Outras características importantes desta geração é que seus componentes valorizam intensamente a interação com o mundo à sua volta e a forma como lidam com as pessoas e seus relacionamentos, e por isso buscam constantemente conexão com as coisas e com as pessoas. Exigem transparência de seus líderes, querem respostas diretas e claras e estão dispostos a lutarem por seus sonhos (OLIVEIRA, 2010).

Esses jovens também foram criados em meio a um ambiente de feedback constante, pelo fato de sua educação ter sido baseada em punições e recompensas de acordo com seus resultados. Esse sistema cria uma necessidade de gratificação instantânea (OLIVEIRA, 2010).

Conforme os millenials vão se empenhando cada vez mais em suas carreiras, o fator remuneração passa a ser uma forma de o profissional saber se está ou não agindo corretamente. Dessa maneira, eles estão interessados neste fator mais como forma palpável de feedback do que por questões financeiras (TULGAN, 2009, apud RUDGE et al., 2017).

Oliveira (2010, p. 104) afirma que os representantes dessa geração “(...) são extremamente vulneráveis, pois não possuem referências suficientes para 
agir com todas as habilidades que conseguem obter em um curto período de tempo".

Na visão dos jovens millenials, a empresa ideal é aquela que apresenta:

a) Crescimento de carreira, em que os jovens buscam reconhecimento, melhores posições, estabilidade financeira e emocional, e assumir desafios;

b) Desenvolvimento profissional, em que procuram conhecimento, experiência, aprendizado de novas técnicas, tornarem-se mais capacitados e assim assumirem maiores responsabilidades;

c) Ambiente de trabalho agradável, onde o ambiente não os intimide, proporcione bem estar, o trabalho seja quase um lazer, constante criação, respeito e bom relacionamento com os colegas;

d) Bons salários e benefícios, e para isso eles buscam maior responsabilidade e maior salário, além de salário compatível com os cargos que ocupam, estabilidade financeira e segurança, e por último reconhecimento dos outros, perante suas conquistas;

e) Oferece cursos e treinamentos, a fim de crescer junto com a empresa, adquirir melhor ferramenta para o conhecimento e se aperfeiçoarem na área de trabalho à qual pertencem. Esses itens indicam que cada vez mais esses jovens querem viver em um ambiente de trabalho agradável, onde possam ser notados e mostrarem tudo aquilo que são capazes (OLIVEIRA, 2010).

Finalmente, Oliveira (2010, p. 118) afirma que esta geração "é bastante prodigiosa em sua capacidade criativa, apresentando uma infinidade de idéias e propostas para modificar as circuntâncias do mundo à sua volta". Isso permite entender melhor o porquê de muitas vezes optarem por abrirem sua própria empresa ao invés de trabalhar dentro de uma organização, já que se acham aptos a criar algo novo ou diferente daquilo que já existe.

\subsubsection{A Geração Y e o Empreendedorismo}

A pesquisa feita pela FIRJAN (2016) aponta que para esses jovens o empreendedorismo vai muito além de uma "decisão de carreira" e afirma que:

A Geração Y enfrenta conflitos e paradoxos como não ter medo de mudanças, estar o tempo todo em movimento, em busca do que deseja e, ao mesmo tempo, sentir uma paralisação excessiva, um não querer buscar algo novo porque, afinal, tudo já foi inventado. 
Além disso, valoriza a liberdade e não está disposta a sacrificar a vida pessoal em nome do trabalho, o que conflita com o empreender (FIRJAN, 2016, p. 5).

Os empreendedores brasileiros, pertencentes à Geração $\mathrm{Y}$, compartilham de algumas características e valores como: o apego à família $(85,3 \%)$, sempre veem o lado positivo das coisas $(69,8 \%)$, têm metas e objetivos bem definidos $(69,7 \%)$, possuem o desejo ético $(68,3 \%)$, têm como desejo mudar o mundo $(66,2 \%)$, se preocupam com causas ambientais $(65,4 \%)$, são capazes de realizar diversas tarefas ao mesmo tempo $(62,0 \%)$, são totalmente ligados em tecnologia $(60,7 \%)$, resolvem tudo de maneira rápida $(60,7 \%)$, tomam ações práticas de caráter social $(60,3 \%)$, são organizados $(59,7 \%)$, não têm medo de correr riscos e fracassar (55,8\%), colocam em prática suas idéias $(54,6 \%)$ e são pessoas plenamente realizadas $(46,1 \%)$ (FIRJAN, 2016).

Além disso, no âmbito das relações do trabalho, também compartilham do gosto pela liderança $(61,7 \%)$, se preocupam em manter um bom networking $(57,2 \%)$, buscam constantemente novas oportunidades $(46,5 \%)$, são comprometidos com o trabalho $(45,2 \%)$ e acreditam que o reconhecimento e a satisfação pessoal no trabalho são mais importantes do que um salário alto (41,7\%) (FIRJAN, 2016).

Existem algumas características que tanto os jovens da Geração Y como os empreendedores têm em comum: a) são criativos, pois tanto os $Y$ quanto os empreendedores apresentam uma infinidade de idéias ou estão buscando uma nova forma de interpretar algo que já exista; b) são indivíduos que querem fazer a diferença, uma vez que os dois procuram mudar as coisas à sua volta; c) são determinados e dinâmicos, tendo em vista o fato dos dois serem extremamente comprometidos com suas ações e tarefas, e estarem em constante movimento e em busca de mudanças; d) possuem conhecimento, devido ao fato de ambos terem fácil acesso à internet e quererem constantemente aprender (OLIVEIRA, 2010; DORNELAS, 2014) 


\section{Métodos e procedimentos de coleta e de análise de dados do estudo}

Esse capítulo apresenta de que maneira os dados necessários para a pesquisa foram coletados e tratados.

\subsection{Método de pesquisa utilizado}

Para fins de metodologia, foram adotados os conceitos de Vergara (2000) que divide a pesquisa em dois critérios básicos, sendo o primeiro quanto aos fins, podendo ser classificada como exploratória, descritiva, explicativa, metodológica, aplicada e intervencionista. O segundo critério é quanto aos meios, podendo ser pesquisa de campo, pesquisa de laboratório, documental, bibliográfica, experimental, ex post facto, participante, pesquisa-ação e estudo de caso.

Com relação aos fins, a pesquisa se classifica como explicativa, a qual segundo Vergara (2000, p. 47) visa "(...) esclarecer quais fatores contribuem, de alguma forma, para a ocorrência de determinado fênomeno". A pesquisa procurou entender o que tem motivado os jovens da Geração $Y$ a abrirem o próprio negócio.

Já com relação aos meios, a pesquisa foi de campo e bibliográfica. De campo, uma vez que foi realizada a partir da investigação de um determinado fenômeno no local em qual ocorre ou ocorreu ou que possua elementos que possam explicá-lo. Essa pode incluir a aplicação de estrevistas, que foi o método utilizado no presente estudo. Além disso, também se caracterizou como pesquisa bibliográfica, a qual consiste em um estudo estruturado com base em materiais publicados em livros, revistas, redes eletrônicas, jornais, ou materiais de acesso público (VERGARA, 2000). 


\subsection{Fontes de informação selecionadas para coleta de dados no estudo}

A pesquisa foi aplicada em jovens nascidos entre 1980 e 1999, período no qual a Geração Y está inserida, conforme Oliveira (2011). Foram selecionados dez empreendedores, residentes da cidade do Rio de Janeiro, que já tenham aberto o próprio negócio e que possuam CNPJ ativo.

A coleta de dados foi de caráter bibliográfico, uma vez que foi feito um estudo sistematizado com base em materiais públicados em livros e artigos (VERGARA, 2000).

A autora afirma existirem dois tipos de amostra: a probabilística - que pode ser a aleatória simples, a estratificada e a por conglomerado - e a não probabilística - por acessibilidade e por tipicidade. Esta pesquisa foi realizada com uma amostra não probabilística por acessibilidade, em que não foram utilizados procedimentos estatísticos, e seus participantes foram selecionados pela facilidade de acesso (VERGARA, 2000).

\subsection{Procedimentos e instrumentos da coleta de dados utilizados no estudo}

O procedimento utilizado no presente estudo foi a entrevista, tendo sido feitas perguntas, para cada entrevistado, individualmente. Vergara (2000) define três tipos de entrevista: informal, focalizada ou por pautas. Para a coleta de dados foram utilizadas entrevistas por pauta, nas quais diversos pontos foram abordados e explorados com o entrevistado.

$\mathrm{O}$ instrumento dividiu-se em três principais partes. A primeira continha doze perguntas, voltadas para entender melhor como é a vida desses empreendedores e como foi o processo de empreender. Primeiramente, os entrevistados eram questionados sobre o ramo da sua empresa, de que forma ela atua, se possui sócios e a idade e experiência de cada um, de quem foi a ideia do negócio, se a empresa possui CNPJ, quantos empregados, se o entrevistado sobrevive com $100 \%$ dos valores que recebe da empresa, qual a experiência dele antes de abrir seu próprio negócio e qual foi a maior facilidade e dificuldade que enfrentou ao longo do processo empreendedor.

A segunda parte da entrevista foi composta por seis perguntas. O objetivo era entender o que uma empresa ideal deve proporcionar para o entrevistado, 
identificar algumas caracteríticas que possui, tanto com relação à geração $Y$ quanto como empreendedor, saber sua opinião quanto à escolha que os jovens da sua idade fazem entre empreender ou trabalhar dentro de uma organização, quais os principais valores que ele determina possuir e identificar quais comportamentos básicos de empreendedor ele demonstra.

A terceira parte foi composta por duas perguntas que pretendiam compreender de forma mais direta o problema do estudo. Foi perguntado a principal motivação desses jovens para empreender e identificar qual foi a maior lição aprendida ao longo do processo de empreender.

Antes da aplicação definitiva da entrevista, o instrumento de coleta foi inicialmente testado com dois entrevistados, para verificar o entendimento de todas as perguntas. Após esta aplicação, foram feitos alguns ajustes e o modelo utilizado segue no Apêndice 1.

\subsection{Formas de tratamento e análise dos dados coletados para o estudo}

Vergara (2000) afirma que o tratamento dos dados é a seção na qual é explicitado como se pretende tratar os dados coletados, e que seja justificado por que esse tratamento é adequado aos propósitos do projeto.

Estabelece também que os dados podem ser tratados de forma quantitativa, qualitativa ou de ambas as maneiras. Neste trabalho, foi utilizado o método qualitativo, em que as respostas serão transcritas, em seguida analisadas, de forma a selecionar, dentro de cada entrevista, aquilo que pode ser aproveitado para o trabalho, e a partir disso interpretar as respostas com base no referencial teórico apresentado.

\subsection{Limitações do Estudo}

Os estudos em geral, assim como este, apresentam limitações, as quais serão discutidas neste tópico. Ao tratar do problema estudado, que no caso é entender o que motiva os jovens da Geração $Y$ a abrirem seus negócios, ou seja, empreender, o presente trabalho não visou representar todos os indivíduos dessa geração, uma vez que foram selecionados jovens que residem somente no Estado do Rio de Janeiro. Além disso, por não existir um consenso com 
relação ao período que representa a Geração Y, como apresentado no capítulo 2, este estudo pode não condizer com determinadas publicações que considerem um período diferente do utilizado. Por fim, o método estará limitado pela seleção das dez pessoas para as entrevistas, tendo em vista a impossibilidade de serem entrevistados todos os empreendedores que possuem um negócio e pertencem à Geração $\mathrm{Y}$. 


\section{Apresentação e análise dos resultados}

\subsection{Descrição e análise dos resultados}

Esta seção apresenta os dados obtidos com os respondentes da pesquisa e as referidas análises com base no referencial teórico apresentado. Além de informações acerca da vida desses empreendedores, também foram analisadas as suas características, valores e sua principal motivação para abrir seu empreendimento. A pesquisa foi respondida por dez membros da geração $Y$ que tinham aberto a própria empresa. Foram exploradas nas entrevistas as principais motivações da geração $\mathrm{Y}$ em ter seu próprio empreendimento.

\subsection{Perfil dos respondentes}

Os dez entrevistados nasceram entre 1987 e 1997. A Tabela 3 mostra que a maior concentração dos jovens se dá na faixa dos 26 aos 29 anos, que representa $60 \%$ da amostra, seguida da faixa de 22 a 25 anos, com $20 \%$. O restante encontra-se entre as outras faixas restantes.

Tabela 3: Idade dos respondentes

\begin{tabular}{|c|c|c|}
\hline Resposta & Quantidade & $\%$ \\
\hline 18 a 21 anos & 1 & $10 \%$ \\
\hline 22 a 25 anos & 2 & $20 \%$ \\
\hline 26 a 29 anos & 6 & $60 \%$ \\
\hline 30 a 33 anos & 1 & $10 \%$ \\
\hline 34 a 37 anos & 0 & $0 \%$ \\
\hline Acima de 37 anos & 0 & $0 \%$ \\
\hline Total & $\mathbf{1 0}$ & $\mathbf{1 0 0}$ \\
\hline
\end{tabular}

Fonte: Próprio autor (2018)

Quanto à graduação, 10\% estão cursando alguma faculdade, os outros $90 \%$ já estão formados em algum curso. A Tabela 4 exibe a relação dos cursos realizados pelos respondentes. Conforme demonstrado, 30\% cursou Engenharia, 20\% Relações Internacionais e os outros $50 \%$ se dividem em outros cursos apresentados na mesma tabela. 
Tabela 4: Curso de graduação dos respondentes

\begin{tabular}{|c|c|c|}
\hline Resposta & Quantidade & $\%$ \\
\hline Administração & 1 & $10 \%$ \\
\hline Direito & 1 & $10 \%$ \\
\hline Design & 1 & $10 \%$ \\
\hline Ecologia & 1 & $10 \%$ \\
\hline Engenharia & 3 & $30 \%$ \\
\hline Medicina & 1 & $10 \%$ \\
\hline Relações Internacionais & 2 & $20 \%$ \\
\hline Total & $\mathbf{1 0}$ & $\mathbf{1 0 0} \%$ \\
\hline
\end{tabular}

Fonte: Próprio autor (2018)

Em relação à sociedade da empresa, $80 \%$ deles alegou possuir ao menos um sócio, sendo que: $30 \%$ possui apenas uma única pessoa atuando em conjunto com o entrevistado em questão, 30\% possui outros dois sócios, 10\% possui quatros sócios e 10\% tem oito sócios. Dentre os vinte um - soma de todos os sócios que cada entrevistado possui - aproximadamente $81 \%$ são pertencentes à geração $Y$ e os demais às gerações restantes. A informação indica que os $\mathrm{Y}$, na hora de abrir a própria empresa, de forma geral, optam por pessoas com idades semelhantes a dele próprio. Com relação ao sexo, a proporção é aproximadamente $81 \%$ de homens e os outros $19 \%$ de mulheres. Sobre a formação desses sócios, $91 \%$ já é formado em algum curso e os outros 9\% ainda estão cursando alguma graduação. Em respeito à experiência anterior de trabalho, aproximadamente $13,6 \%$ não possuem nenhuma experiência corporativa, 9,1\% foram apenas estagiários em alguma empresa e os outros $77,3 \%$ já trabalharam em pelo menos uma empresa antes de se tornarem empreendedores. Na grande maioria (80\%) a ideia partiu do próprio entrevistado, sendo que dos outros $20 \%$ a ideia surgiu de seus sócios, em que esses não são pertencentes à geração $\mathrm{Y}$.

Em seguida foi perguntado quanto tempo a empresa tem de mercado. Das dez empresas, $40 \%$ têm até um ano de atuação, $40 \%$ têm de dois a três anos e $20 \%$ delas estão operando entre quatro e cinco anos.

Os entrevistados também foram questionados em relação a se sobrevivem totalmente dos valores que recebem do seu empreendimento. Tal fator ficou bastante dividido entre os entrevistdos, onde $60 \%$ alegou sobreviver integralmente dos lucros de seu negócio e os outros $40 \%$ ainda não.

$\mathrm{Na}$ sequência procurou-se compreender, brevemente, a experiência de cada um antes de abrir o próprio negócio, no qual 10\% declararam não possuir nenhuma experiência corporativa anterior, e que ainda estavam cursando 
faculdade, outros $10 \%$ foram apenas estagiários em alguma organização e os $80 \%$ restantes trabalharam em empresas privadas antes de começarem a empreender.

A última pergunta dessa sessão visava identificar as facilidades e dificuldades que os empreendedores tiveram enquanto estavam no início do processo do empreender. Dois dos entrevistados alegaram que a maior facilidade foi a de trabahar com o que gosta e naquilo que acredita. Outros dois afirmaram que a maior dificuldade que tiveram foi a burocracia para se abrir uma empresa, uma vez que no Brasil esse processo é extremamente dificil e cansativo. As demais respostas não tiveram consistência e por isso não foram levadas em consideração.

\subsection{Geração Y e Empreendedorismo}

A segunda parte do roteiro foi composta por perguntas que procuraram entender melhor as principais características dos empreendedores e da Geração $\mathrm{Y}$, além dos seus valores. Foi pedida também a opinião deles em relação a se eles achavam que as pessoas da sua idade tem mais tendência a trabalhar ou empreender e por fim quais comportamentos básicos de empreendedores eles possuem.

Com relação ao que a empresa ideal deve proporcionar para o entrevistado, considerando uma escala de 1 a 5 , onde 1 foi definido como mais importante, 2 muito importante, 3 importante, 4 pouco importante e 5 menos importante, foram obtidas respostas bastante interessantes. A tabela 5 apresenta na primeira coluna uma lista dos fatores que a empresa ideal deve possuir segundo Oliveira (2010). A primeira linha traz a ordem de importância de cada um dos itens e as demais, a quantidade de entrevistados que respondeu 0 quanto determinado item era importante. Para a realização da análise dos dados, será levado em consideração as pessoas que atribuíram alguma importância, ou seja, entre 1 e 3 para cada item listado. Conforme indicado na Tabela 5, 90\% (soma das respostas de 1 a 3 ) determinou que o desenvolvimento profissional é quesito fundamental que uma empresa deve possuir. Já com relação a um ambiente de trabalho agradável, $80 \%$ identificou ser de alta importância dentro de uma organização. Crescimento de carreira foi citado por $70 \%$ dos respondentes. Já $60 \%$ dos entrevistados afirmou que bons salários e benefícios têm relevância também significativa. $O$ item cursos e treinamentos foi 
considerado sem importância, ou seja, 100\% dos entrevistados o avaliou entre pouco importante e menos importante.

Tabela 5: Fatores que a empresa ideal deve proporcionar

\begin{tabular}{|l|l|l|l|l|l|}
\cline { 2 - 6 } \multicolumn{1}{c|}{} & $\mathbf{1}$ & $\mathbf{2}$ & $\mathbf{3}$ & $\mathbf{4}$ & $\mathbf{5}$ \\
\hline Desenvolvimento profissional & 6 & 2 & 1 & 1 & 0 \\
\hline Ambiente de trabalho agrdável & 1 & 4 & 3 & 2 & 0 \\
\hline Crescimento de carreira & 3 & 2 & 2 & 0 & 3 \\
\hline Bons salários e benefícios & 0 & 2 & 4 & 3 & 1 \\
\hline Oferecer cursos e treinamento & 0 & 0 & 0 & 4 & 6 \\
\hline
\end{tabular}

Fonte: Próprio autor (2018)

Segundo Oliveira (2010), os jovens $Y$ buscam por empresas que proporcionem crescimento de carreira, desenvolvimento profissional, ambiente de trabalho agradável, bons salários e benefícios e ofereçam cursos e treinamentos. Considerando a amostragem em questão, há concordância com o autor, exceto no quesito de oferecer cursos e treinamentos, cujo resultado contradiz essa afirmativa, uma vez que nenhum dos entrevistados declarou que esse item possui alguma importância para si. Desta forma, uma empresa que ofereça cursos e treinamentos não seria valorizada pelos jovens dessa geração, uma vez que nenhum deles a classificou entre os itens 1 e 3.

No que se refere às características dos jovens $\mathrm{Y}$, foi mostrada uma lista com diversos atributos apresentados anteriormente pelos autores citados, e em seguida solicitado aos entrevistados que dessem uma nota de 0 a 10, referente a quanto eles consideravam possuir determinadas características. A Tabela 6 apresentou uma média de notas dada a cada um dos atributos. Para Oliveira (2011), esses jovens são muito bem informados, porém essa foi uma das notas mais baixas obtidas nas entrevistas, sendo de 7,9, perdendo apenas para hiperatividade $(7,3)$. Com relação a dominar com faclidade tecnologias, uma vez que cresceram em meio a um grande avanço tecnológico, esse quesito teve nota 8,4 . Esses jovens também são considerados muito curiosos $(9,5)$, uma vez que estão sempre em busca de saber cada vez mais, são ambiciosos $(8,8)$, procurando sempre alcançar seus objetivos, porém não são tão comunicativos $(8,3)$ e nem possuem tanta segurança para arriscar $(8,2)$ como apresentado pelo autor.

Oliveira (2010) alega que esses jovens valorizam intensamente a interação com o mundo e buscam constante conexão com as coisas e as pessoas, o que condiz, de certa forma, com os resultados da pesquisa, visto que esse quesito 
teve nota de 8,8, a qual está acima da média. Além disso, eles são conhecidos por lutarem por seus sonhos, fato comprovado nas pesquisas, uma vez que foi o atributo com nota mais alta apresentada $(9,6)$, mostrando que eles querem ir em busca daquilo em que acreditam e almejam para si.

Para Lipkin e Perrymore (2010), essa geração é exigente, o que condiz com aquilo apresentado pelos entrevistados, visto que apresentou nota 8,7, e tem desejo de fazer a diferença e se mostrarem para o mundo, que foi a segunda maior nota apresentada $(9,5)$.

E por último, esses jovens são considerados por ambos os autores como criativos e por isso possuem tendência a empreender, porém a partir dos resultados apresentados a criatividade não é tão presente na vida desses jovens, já que foi a terceira menor nota apresentada $(8,1)$. O que nos coloca um pouco em dúvida a respeito de se esses jovens tem maior predisposição a empreender do que trabalhar dentro de uma empresa.

Tabela 6: Características da Geração Y

\begin{tabular}{|l|c|c|c|c|c|c|c|c|c|c|c|}
\cline { 2 - 11 } \multicolumn{1}{l|}{} & $\mathbf{1}$ & $\mathbf{2}$ & $\mathbf{3}$ & $\mathbf{4}$ & $\mathbf{5}$ & $\mathbf{6}$ & $\mathbf{7}$ & $\mathbf{8}$ & $\mathbf{9}$ & $\mathbf{1 0}$ & MÉDIA \\
\hline Luta pelos seus sonhos & - & - & - & - & - & - & - & 1 & 2 & 7 & $\mathbf{9 , 6}$ \\
\hline Curioso & - & - & - & - & - & - & - & 2 & 1 & 7 & $\mathbf{9 , 5}$ \\
\hline $\begin{array}{l}\text { Desejo de fazer a } \\
\text { diferença }\end{array}$ & - & - & - & - & - & - & - & 1 & 3 & 6 & $\mathbf{9 , 5}$ \\
\hline Ambicioso & - & - & - & - & - & 2 & - & 1 & 2 & 5 & $\mathbf{8 , 8}$ \\
\hline $\begin{array}{l}\text { Valoriza a interação } \\
\text { com o mundo }\end{array}$ & - & - & - & - & - & - & 2 & 3 & - & 5 & $\mathbf{8 , 8}$ \\
\hline Exigente & - & - & - & - & - & 1 & 1 & 2 & 2 & 4 & $\mathbf{8 , 7}$ \\
\hline $\begin{array}{l}\text { Domina com facilidade } \\
\text { tecnologias }\end{array}$ & - & - & - & - & - & - & 3 & 2 & 3 & 2 & $\mathbf{8 , 4}$ \\
\hline Comunicativo & - & - & - & - & - & 3 & - & 1 & 3 & 3 & $\mathbf{8 , 3}$ \\
\hline Seguro para arriscar & - & - & - & - & - & 1 & 3 & 2 & 1 & 3 & $\mathbf{8 , 2}$ \\
\hline Criativo & - & - & - & - & - & - & 3 & 4 & 2 & 1 & $\mathbf{8 , 1}$ \\
\hline Informado & - & - & - & - & - & - & 2 & 7 & 1 & - & $\mathbf{7 , 9}$ \\
\hline Hiperativo & - & - & - & - & 1 & 3 & 2 & 2 & - & 2 & $\mathbf{7 , 3}$ \\
\hline
\end{tabular}

Fonte: Próprio autor (2018)

$\mathrm{Na}$ sequência, os empreendedores foram questionados sobre o fato de acharem que as pessoas da sua idade tem maior tendência a empreender ou a trabalhar dentro de uma organização. Essa pergunta ficou bastante dividida entre os respondentes, uma vez que $50 \%$ alegou que os jovens da sua idade tem mais tendência a trabalharem dentro de uma empresa, devido à falta de recursos para abrir seu próprio negócio; falta de maturidade e confiança para 
seguir suas ideias e falta de incentivo e estímulo ao empreendedorismo no Brasil. Já os outros $50 \%$ acreditam que eles possuem mais tendência a empreender, e alegam que isso se dá pela insatisfação com o meio corporativo; a burocracia dentro das empresas; o fato do empreendedorismo estar na moda e por isso muita gente tentar empreender; por priorizarem valores como experiência de vida ao invés de valores materiais; perceberem que, na maioria, os pais são frustrados com suas carreiras e por isso estão mais dispostos a arriscar e serem felizes fazendo aquilo que gostam e se orgulham, e colocarem a felicidade a frente do dinheiro.

Em seguida, foi perguntado para os entrevistados a respeito dos valores que eles dizem possuir. A Tabela 7 apresenta uma lista de valores pessoais, apresentados pela FIRJAN (2016) e exatamente o que cada um respondeu a respeito de possuir ou não aquele valor. Pela tabela é possível verificar que $100 \%$ dos entrevistados alegam ser ligados em tecnologia o que não condiz com a pesquisa apresentada pelo órgão, em que apenas 60,7\% dos empreendedores da geração $Y$ entrevistados dizem possuir esse valor. Já o apego a família em ambas as pesquisas foi relativamente próximo tendo $90 \%$ contra $85 \%$. Sempre ver o lado positivo das coisas teve uma diferença de $20,2 \%$ entre as duas pesquisas, mas ambas tiveram valores significativos. Sempre ver o lado positivo das coisas, ter metas e objetivos bem definidos, desejo ético e desejo de mudar o mundo caminham lado a lado entre as duas, que apesar de porcentagens diferentes, seguem a mesma ordem dentro da listagem dos valores.

Colocar em prática suas ideias já apresenta uma diferença mais significativa, uma vez foi citado por $90 \%$ dos jovens contra $54,6 \%$, diferença de $35,4 \%$, e para um empreendedor colocar em prática suas ideias é de grande importância para que as coisas se concretizem. Os atributos organização e ser capaz de realizar diversas tarefas ao mesmo tempo não estão pareados entre as duas pesquisas e apresentam diferenças de 20,3\% e 10,2\% respectivamente.

Por último, preocupar-se com causas ambientais, resolver tudo de maneira rápida, tomar ações práticas de caráter social e ser plenamente realizado possuem pouca ou nenhuma diferença entre as duas pesquisas, o que nos mostra uma equivalência nesses quesitos. 
Tabela 7: Valores da geração $Y$

\begin{tabular}{|c|c|c|c|c|c|c|c|c|c|c|c|c|}
\hline & 1 & 2 & 3 & 4 & 5 & 6 & 7 & 8 8 & 9 & 10 & $\%$ & $\%$ Firjan \\
\hline Ligado em tecnologia & $x$ & $\mathrm{X}$ & $\mathrm{X}$ & $\mathrm{X}$ & $\mathrm{X}$ & $\mathrm{X}$ & $\mathrm{X}$ & $x \mid>$ & $\mathrm{X}$ & $\mathrm{X}$ & $100 \%$ & $60,70 \%$ \\
\hline Apego à família & $x$ & $\mathrm{X}$ & & $\mathrm{X}$ & $\mathrm{X}$ & $\mathrm{X}$ & $\mathrm{X}$ & $x \mid \gamma$ & $\mathrm{X}$ & $x$ & $90 \%$ & $85,30 \%$ \\
\hline $\begin{array}{l}\text { Sempre ver o lado positivo } \\
\text { das coisas }\end{array}$ & $x$ & $\mathrm{X}$ & & $\mathrm{X}$ & $\mathrm{X}$ & $\mathrm{X}$ & $\mathrm{X}$ & $\mathrm{x}>$ & $\mathrm{X}$ & $\mathrm{X}$ & $90 \%$ & $69,80 \%$ \\
\hline $\begin{array}{l}\text { Metas e objetivos bem } \\
\text { definidos }\end{array}$ & $x$ & $X$ & $\mathrm{X}$ & & $\mathrm{X}$ & $\mathrm{X}$ & $\mathrm{X}$ & $x \mid \gamma$ & $X$ & $\mathrm{X}$ & $90 \%$ & $69,70 \%$ \\
\hline Desejo ético & $\mathrm{X}$ & $\mathrm{X}$ & $\mathrm{X}$ & $\mathrm{X}$ & $\mathrm{X}$ & $\mathrm{X}$ & $\mathrm{X}$ & $\mathrm{x}$ & & $\mathrm{X}$ & $90 \%$ & $68,30 \%$ \\
\hline Desejo de mudar o mundo & $\mathrm{X}$ & $\mathrm{X}$ & $\mathrm{X}$ & $\mathrm{X}$ & $\mathrm{X}$ & $\mathrm{X}$ & $\mathrm{X}$ & $\mathrm{X}$ & $\mathrm{X}$ & & $90 \%$ & $66,20 \%$ \\
\hline $\begin{array}{l}\text { Coloca em prática suas } \\
\text { ideias }\end{array}$ & $x$ & $\mathrm{X}$ & $\mathrm{X}$ & $\mathrm{X}$ & $x$ & $\mathrm{X}$ & $\mathrm{X}$ & $x)$ & $\mathrm{X}$ & & $90 \%$ & $54,60 \%$ \\
\hline Organização & $x$ & $X$ & $X$ & $\mathrm{X}$ & $\mathrm{X}$ & $\mathrm{x}$ & $\mathrm{X}$ & $x$ & & & $80 \%$ & $59,70 \%$ \\
\hline $\begin{array}{l}\text { Preocupa-se com causas } \\
\text { ambientais }\end{array}$ & $\mathrm{X}$ & $\mathrm{X}$ & $\mathrm{X}$ & & $\mathrm{X}$ & $X$ & $\mathrm{X}$ & $\mathrm{x}$ & & & $70 \%$ & $65,40 \%$ \\
\hline $\begin{array}{l}\text { Capaz de realizar diversas } \\
\text { tarefas ao mesmo }\end{array}$ & $x$ & $\mathrm{X}$ & $\mathrm{X}$ & $\mathrm{X}$ & $X$ & $X$ & $\mathrm{X}$ & & & & $70 \%$ & $62 \%$ \\
\hline $\begin{array}{l}\text { Resolve tudo de maneira } \\
\text { rápida }\end{array}$ & $x$ & $\mathrm{X}$ & $\mathrm{X}$ & & & & & $\mathrm{X}$ & $x$ & $X$ & $60 \%$ & $60,60 \%$ \\
\hline $\begin{array}{l}\text { Toma ações de caráter } \\
\text { social }\end{array}$ & $X$ & $\mathrm{X}$ & $\mathrm{X}$ & $\mathrm{X}$ & & $\mathrm{X}$ & & $\mathrm{X}$ & & & $60 \%$ & $60,30 \%$ \\
\hline Plenamente Realizado & $x$ & & & & $\mathrm{X}$ & & $\mathrm{X}$ & & $\mathrm{x}$ & & $40 \%$ & $46,10 \%$ \\
\hline
\end{tabular}

Fonte: Próprio autor (2018)

Considerando as características que um empreendedor deve possuir, apresentadas por Dornelas (2014), foi pedido que os entrevistados avaliassem de 0 a 10 o quanto eles consideravam possuir de determinada característica. A Tabela 8 apresenta uma média das notas dadas. Os quesitos com nota mais alta $(9,7)$ foram a dedicação, em que é preciso ter total comprometimento com seu negócio, e otimismo, pois por terem amor pelo que fazem estão cada vez mais animados em alcançar o sucesso. Em seguida eles são determinados e dinâmicos $(9,5)$, uma vez que ultrapassam obstáculos para fazer acontecer, e bem relacionados $(9,1)$, devido ao fato de o networking ser fundamental para promover sua empresa.

Esses jovens empreendedores também afirmam fazer a diferença $(8,7)$, para assim trazerem algo novo para o mercado, e serem organizados, característica de extrema importância para um empreendedor, já que esse fator permite maior desempenho do negócio. Outros três atributos avliados como importantes são que esses jovens sabem tomar decisões, explorar oportunidades, ambos com nota 8,1 , e sabem planejar $(8,0)$. Tais fatores são importantes para que eles não se sintam inseguros na hora de mudar algo, enxerguem oportunidades como estratégias para obter crescimento e sucesso, e 
planejarem cada passo minuciosamente de forma a diminuirem erros e gerarem resultados positivos (DORNELAS, 2014).

Por último, as duas características que tiveram menores notas foram a independência $(7,7)$, uma vez que parte desses jovens ainda depende da família ou de sócios investidores para seguirem em frente, e o fato de se considerarem visionários $(7,3)$, em que eles ainda não tem uma visão muito clara de como será o futuro e o que os aguarda, muitas vezes pelo fato de ainda serem muito novos a ponto de enxergarem tão a frente como empreendedores de sucesso geralmente fazem.

Tabela 8: Características do empreendedor

\begin{tabular}{|l|c|c|c|c|c|c|c|c|c|c|c|}
\cline { 2 - 9 } \multicolumn{1}{c|}{} & $\mathbf{1}$ & $\mathbf{2}$ & $\mathbf{3}$ & $\mathbf{4}$ & $\mathbf{5}$ & $\mathbf{6}$ & $\mathbf{7}$ & $\mathbf{8}$ & $\mathbf{9}$ & $\mathbf{1 0}$ & MÉDIA \\
\hline Dedicado & - & - & - & - & - & - & - & - & 3 & 7 & $\mathbf{9 , 7}$ \\
\hline Otimista & - & - & - & - & - & - & 1 & 3 & - & 6 & $\mathbf{9 , 7}$ \\
\hline Determinado e dinâmico & - & - & - & - & - & - & - & 1 & 3 & 6 & $\mathbf{9 , 5}$ \\
\hline Bem relacionado & - & - & - & - & - & - & 1 & 2 & 2 & 5 & $\mathbf{9 , 1}$ \\
\hline Líder e formador de equipe & - & - & - & - & - & - & 1 & 3 & 3 & 3 & $\mathbf{8 , 8}$ \\
\hline Faz a diferença & - & - & - & - & - & - & 1 & 3 & 4 & 2 & $\mathbf{8 , 7}$ \\
\hline Organizado & - & - & - & - & - & - & 1 & 2 & 1 & 5 & $\mathbf{8 , 6}$ \\
\hline Sabe tomar decisões & - & - & - & - & - & 2 & 2 & 2 & 1 & 3 & $\mathbf{8 , 1}$ \\
\hline Sabe explorar oportunidades & - & - & - & - & 1 & 1 & 2 & 1 & 2 & 3 & $\mathbf{8 , 1}$ \\
\hline Sabe planejar & - & - & - & - & 1 & - & 2 & 4 & 1 & 2 & $\mathbf{8}$ \\
\hline Independente & - & - & - & - & 1 & 1 & 1 & 5 & 1 & 1 & $\mathbf{7 , 7}$ \\
\hline Visionário & - & - & - & - & - & 3 & 3 & 2 & 2 & - & $\mathbf{7 , 3}$ \\
\hline
\end{tabular}

Fonte: Próprio autor (2018)

Na última pergunta da segunda parte da pesquisa foram apresentados os dez comportamentos básicos dos empreendedores divididos nos três grupos: "realização", "planejamento" e "poder", desenvolvidos por McClelland. Foi dada a eles uma lista com 30 comportamentos, em que se encaixavam dentro dos dez, e pedido que respondessem se eles possuiam ou não determinada atitude, podendo escolher mais de um parâmetro e, dessa forma podendo chegar a uma soma superior a $100 \%$.

No conjunto "realização", com relação à busca de oportunidades e iniciativas, $100 \%$ responderam realizarem atividades antes do solicitado ou forçado pelas circunstâncias, e buscaram novas áreas de atuação para ampliarem seu empreendimento. Por outro lado, 60\% alegaram aproveitar oportunidades fora do comum para começar um negócio novo. A pesquisa revelou que esses jovens são extremamente persistentes, uma vez que 100\% 
deles declararam agir diante de dificuldades relevantes, insistir ou mudar de estratégia com a finalidade de enfrentar desafios ou dificuldades, e responsabilizarem-se pessoalmente pelo cumprimento dos objetivos estabelecidos.

Já em relação a correr riscos calculados, os entrevistados não apresentaram possuir tal comportamento, uma vez que $80 \%$ agem para diminuir riscos e controlar resultados, e apenas $60 \%$ analisam as alternativas e calculam risco cuidadosamente e $50 \%$ colocam-se em situações que implicam desafios moderados, desde que os riscos sejam calculados, o que nos permite entender que esses jovens procuram se jogar de cabeça em uma ideia sem se preocuparem com as devidas consequências. Os entrevistados mostraram serem exigentes, visto que $90 \%$ agem de forma a executar melhor as coisas, mais rapidamente ou mais barato, e $80 \%$ afirmaram proceder de forma a realizar coisas que satisfaçam ou excedam aos padrões de excelência e asseguram que o trabalho seja terminado a tempo e atendam aos padrões de qualidade estabelecidos. Eles também se mostraram bastante comprometidos com 0 negócio, em que 100\% trabalham junto com seus empregados ou os substuituem caso seja necessário finalizar determinada tarefa, 90\% primam por manter os clientes satisfeitos e priorizam a boa vontade em longo prazo ao invés de lucro em curto prazo, e $80 \%$ sacrificam-se pessoalmente ou realizam grande esforço a fim de terminar um tarefa contratada.

Dentro do bloco "planejamento" foi notado que eles se preocupam em buscar informações pessoalmente, porém não é algo tão primordial, pois $90 \%$ solicitam orientação de especialistas para obter assessoria técnica ou comercial, a fim de possibilitar a elaboração de estratégias racionais, $80 \%$ pesquisam pessoalmente sobre como fabricar um produto ou oferecer um serviço e $70 \%$ pesquisam pessoalmente informações de clientes, fornecedores e concorrentes. Esse comportamento é importante para que os empreendedores consigam saber cada vez mais sobre o seu negócio e assim aprimorá-lo. Com relação ao estabelecimento de metas, $100 \%$ indicou fixar objetivos de curto prazo e mensuráveis, $80 \%$ fixam objetivos que lhes proporcionem desafios e significado pessoal, porém apenas $40 \%$ alegaram fixar metas de longo prazo, claras e específicas, o que pode indicar que esses jovens estão mais preocupados com o agora do que o futuro.

Quanto ao planejamento e monitoramento sistemático, 70\% desses jovens planejam um trabalho grande e o dividem em partes mais simples e com prazos definidos, de forma a facilitar a execução, e acompanham e revisam seus 
planos, embasados em informações sobre o real desempenho e em novas circunstâncias, porém apenas 50\% mantêm registros financeiros e os utilizam para tomar decisões, o que é de fato crítico, visto que um empreendedor precisa ter noção de suas finanças para poder levar um projeto adiante ou não.

No grupo "poder" percebeu-se que os jovens ficaram levemente divididos em relação à independência e autoconfiança, visto que apesar de $100 \%$ deles se mostrarem confiantes na sua própria capacidade de completar uma tarefa difícil ou de enfrentar um desafio, $70 \%$ costumam analisar as situações-problema no sentido de avaliar as fraquezas e as ameaças de suas ações a fim de eliminá-las ou amenizá-las, e apenas $50 \%$ mantêm suas decisões, mesmo quando os outros se opõem diante de resultados desanimadores. Isso, de certa forma pode ser bom, por estarem dispostos a ouvir a opinião dos outros, para assim tomar uma melhor decisão, mas também pode ser ruim, pois, por serem empreendedores possuem uma melhor visão do negócio do que seus empregados e por isso sabem o que é melhor ou pior para a empresa. Eles também se mostraram bastante persuasivos e alegaram possuir uma boa rede de contatos, dado que agem de forma a desenvolver e manter relações comerciais, 90\% usa de estratégias para influenciar ou persuadir os outros e $80 \%$ usa de pessoas influentes para atingir seus objetivos. Tais comportamentos são importantes, pois é a partir da persuasão e do networking que os empreendedores conseguem convencer as pessoas a investirem ou adquirirem seu produto ou serviço.

A terceira parte da pesquisa buscou compreender o que motiva os jovens millenials a empreender e qual foi a maior lição que eles aprenderam ao longo do processo de empreender.

Primeiro procurou-se responder, agora de forma direta, o problema de pesquisa em questão e para isso os jovens foram questionados a respeito do que motivou cada um deles a abrir o próprio negócio. A pesquisa feita pela Firjan (2016) afirma existirem diversas motivações para empreender. Assim como nos resultados apresentados pela FIRJAN (2016) a realização de um sonho e a busca por qualidade de vida são as principais motivações dos entrevistados ao empreenderem, sendo citadas por $30 \%$ deles. Uma parte dos entrevistados buscou ao empreender fazer aquilo que gostam (20\%), e outros não serem reféns do seu trabalho (10\%), - fatores esses não citados pela FIRJAN - e o desejo de fazerem a diferença (20\%).

Outros motivos apresentados foram: a falta de perspectiva no mercado formal (30\%); a liberdade de não ter chefes (30\%); a liberdade de não possuir 
horários fixos (10\%); e de não precisar de rotina diária (10\%). Isso se dá pelo fato de os entrevistados alegarem não se sentirem confortáveis em trabalhar num modelo tradicional de empresa, uma vez que se sentem inclinados a levarem seus próprios projetos adiante, e em uma organização é necessário a aprovação de um superior para que determinada iniciativa estabelecida seja levada a frente. Além disso, o fato de que do mercado formal tenha maior preocupação no cumprimento de um banco de horas rígido por parte dos funcionários ao invés de poderem montar seus próprios horários e seguirem suas próprias rotinas, desde que tudo seja entregue no prazo estipulado.

Um dos entrevistados alegou que uma das motivações dele foi a possibilidade constante de crescimento (10\%), uma vez que ao ter seu próprio negócio tanto o sucesso quanto o insucesso são méritos e responsabilidade do próprio empresário. Além disso, esse mesmo empreendedor e um outro decidiram empreender por apostarem em um mercado promissor com oportunidade de altos ganhos (20\%), demonstrando que esses indivíduos ao identificarem uma oportunidade, preferem investir nela sozinhos - ou com sócios - ao invés de dentro uma organização.

Apesar de nenhum dos entrevistados ter citado a continuação de um negócio familiar, $20 \%$ deles possuem pais que abriram o próprio negócio e por isso cresceram, de certa forma, em um ambiente propício a empreender, uma vez que os tiveram como inspiração.

Por último nenhum dos entrevistados declarou que uma das motivações foi a busca por respeito e reconhecimento, mostrando que esses jovens não se importam muito com o que os outros pensam a respeito deles e sim com o que os faz feliz.

$\mathrm{Na}$ última pergunta do roteiro, buscou-se saber qual a principal lição que aprenderam ao longo de todo o processo empreendedor. Nessa questão, uma diversidade de opiniões emergiu. Um dos entrevistados diz "(...) não encare como um trabalho e sim como um prazer" (Entrevistado 5). Outros dois alegam que ao empreender você estará lidando com pessoas, e que para isso "É preciso saber Idar com todo e qualquer tipo de pessoa" (Entrevistado 1) e o outro fala que “(...) a gestão de pessoas é super-complexa e super-necessária" (Entrevistado 6).

Três deles consideram extremamente necessário ser organizado em absolutamente tudo, rever seus planejamentos todos os dias, uma vez que "(...) por mais que você se planeje e se programe ao máximo, nada vai sair conforme 
você planejou, tudo mudará aos pouquinhos" (Entrevistado 10), e focar em um nicho para assim gerar resultados mais rapidamente.

Outros dois entrevistados concordam que um empreendedor deve sempre tentar e nunca desistir, pois o que pode parecer ser o fim de tudo pode não ser de fato. Além disso, um dos empreendedores afirma que não é preciso ter medo de errar, pois é com os erros que aprendemos e por isso não devemos nunca desistir, e um último alega que "Tudo tem seu tempo, faça uma coisa de cada vez, não tente dar dois passos com uma perna só, vá com calma" (Entrevistado 2). 


\section{Conclusões e recomendações para novos estudos}

O objetivo deste trabalho foi identificar as principais motivações da Geração $\mathrm{Y}$ ao abrir a própria empresa. Para que esse trabalho fosse concluido, foram primeiramente realizadas pesquisas bibliográficas sobre dois principais temas abordados: empreendedorismo e geração Y. Em relação ao primeiro, foram apresentadas as principais teorias a respeito do que é 0 empreendedorismo, quem é o empreendedor e suas principais características e comportamentos. Já em relação a Geração $Y$, buscou-se compreender as suas principais características, valores e principais tendências. Oliveira (2011) afirma que esses jovens tendem a abrir a própria empresa, uma vez que já entram no mercado de trabalho querendo empreender.

Depois de uma imersão nestes dois assuntos, foi realizada uma pesquisa de campo com dez entrevistados que compõem a Geração Y, residentes do Estado do Rio de Janeiro e que são empreendedores, sendo levado em consideração que abriram a própria empresa. Embora tenham formações diferentes e experiências diversas, foi possível identificar algumas motivações que possuem em comum.

Após as análises realizadas e comparando as entrevistas com os conteúdos bibliográficos foi possível concluir que os jovens entrevistados têm como principais características serem curiosos, possuirem o desejo de fazer a diferença e lutarem pelos seus sonhos, atributos esses que contribuem com a vontade deles de abrirem a própria empresa e como empreendedores são dedicados, otimistas, determinados e dinâmicos.

As entrevistas realizadas identificaram que os respondentes ficaram divididos quando perguntado se eles acham que os jovens da sua idade tem mais tendência a empreender ou a trabalhar dentro de uma empresa, uma vez que os resultados obtidos foram $50 \%$ para ambos.

Além disso, a pesquisa identificou que $20 \%$ dos entrevistados apostaram em mercado promissor e viram uma oportunidade de altos ganhos ao ter a própria empresa. Outros $20 \%$ possuem pais empreendedores e por isso viram desde novos as vantagens de ter o próprio negócio. Outros 30\% dos 
respondentes decidiram empreender por quererem realizar um sonho, buscarem por qualidade de vida, pela liberdade de não ter chefes ou por falta de perspectiva no mercado formal. Ainda, $20 \%$ possuiam o desejo de fazer a diferença, queriam fazer aquilo que gostam e sentem prazer. E finalmente, 10\% não queriam ter rotina diária e nem horários fixos e buscavam por uma oportunidade de crescimento constante.

A partir desta pesquisa foi possível concluir que a principal motivação destes jovens é a realização pessoal, visto que todos os entrevistados citaram ao menos uma vez algum fator de caráter pessoal, e que decidiram empreender por quererem sentir-se bem consigo mesmos e não terem que fazer aquilo que não os agrada e que não os satisfaz pelo resto da vida.

Este estudo contribuiu para que seja possível compreender melhor quais as principais características dos jovens pertencentes à Geração $Y$ e que são empreendedores. Além disso, colaborou para que fosse possível compreender melhor o que motiva os jovens millenials a abrirem a própria empresa.

\subsection{Sugestões e recomendações para novos estudos}

Através deste estudo, buscou-se contribuir com os trabalhos sobre a Geração Y e sobre Empreendedorismo. A partir deste, futuros estudos podem complementar ainda mais esses conhecimentos.

Além disso, sugere-se também buscar compreender melhor se os jovens $Y$ tem mais tendência a empreender ou a trabalhar dentro de uma organização, uma vez que os entrevistados em questão ficaram bastante divididos com relação a essa questão.

Por fim, recomenda-se a aplicação de entrevistas com uma amostragem maior do que a apresentada de forma a ter uma ampla visão sobre a motivação desses jovens e assim identificar melhor quais são elas. Além disso, poderíamos ter um diagnóstico mais profundo das características, tanto dos millenials quanto dos empreendedores da geração $\mathrm{Y}$. 


\section{Referências Bibliográficas}

CARVALHO, P. M. R.; GONZÁLEZ, L. Modelo explicativo sobre a intenção empreendedora. Comportamento Organizacional e Gestão, v. 12, n. 1, p. 43-65, 2006.

DORNELAS, J. C. A. Empreendedorismo: transformando ideias em negócios. 5.ed. Rio de Janeiro: Empreende/ LTC, 2014.

Firjan. Jovens empresários empreendedores, Dez 2016. Disponível em: < http://www.firjan.com.br/lumis/portal/file/fileDownload.jsp?fileld=2C908A8F58D545C 90158DEB35F2B1A68\&inline=1 >. Acesso em: 24 de Junho de 2016.

GEM - Global Entrepreneurship Monitor. Empreendedorismo no Brasil. Curitiba: $\quad$ IBQP, $2015 . \quad$ Disponível em: < http://www.bibliotecas.sebrae.com.br/chronus/ARQUIVOS_CHRONUS/bds/bds.nsf/ c6de907fe0574c8ccb36328e24b2412e/\$File/5904.pdf>. Acesso em 25 de junho de 2017.

GEM - Global Entrepreneurship Monitor. Empreendedorismo no Brasil. Curitiba: $\quad$ IBQP, 2016. Disponível em < http://www.bibliotecas.sebrae.com.br/chronus/ARQUIVOS_CHRONUS/bds/bds.nsf/ 941a51dd04d5e55430088db11a262802/\$File/7592.pdf>. Acesso em 25 de junho de 2017.

GREATTI, L; SENHORINI, V. M. Empreendedorismo: uma visão comportamentalista In: EGEPE - ENCONTRO DE ESTUDOS SOBRE EMPREENDEDORISMO E GESTÃO DE PEQUENAS EMPRESAS. 1. 2000, Maringá, Anais... Maringá, 2000, p.22-34.

LIPKIN, N. A.; PERRYMORE, A. J. A Geração Y no trabalho: como lidar com a força de trabalho que influenciará definitivamente a cultura da sua empresa. Rio de Janeiro: Elsevier, 2010.

OLIVEIRA, S. Geração Y: O nascimento de uma nova geração de líderes. São Paulo: Integrare Editora, 2010.

Geração Y: Ser potencial ou ser talento? Faça por merecer. São Paulo: Integrare, 2011.

RIBAS, R. A motivação empreendedora e as teorias clássicas da motivação. Caderno de Administração, São Paulo, 2011, v 5, n. 11.

ROBINS, S.P; JUDGE, T. A; SOBRAL, F. Comportamento Organizacional. São Paulo: Pearson Prentice Hall, 2010. 
RUDGE, M; REIS, G. G; NAKATA, L; PICCHIAI, D. Geração Y: Um estudo sobre suas movimentações, valores e expectativas. Revista de Carreiras e Pessoas, São Paulo: Jan/Fev/Mar/Abr. 2017.

SALIM, C.; NASAJON, C.; SALIM, H.; MARIANO, S. Administração empreendedora: teoria e prática usando o estudo de casos. Rio de Janeiro: Elsevier, 2004.

TOMEI, P. A; RUSSO, G. M; ANTONACCIO, C. F. B. Cultura Empreendedora Guia prático para seleção de empreendedores. Rio de Janeiro: Office Book Editora, 2008.

VERGARA, S. C. Projetos e relatórios de pesquisa em administração. São Paulo: Atlas, 2000. 


\section{Apêndice 1}

1) Nome:

2) Idade:

3) Escolaridade:

4) Qual o ramo da sua empresa?

5) Você possui sócios? Qual a idade deles? Você possui sócios? Qual o sexo? Qual a formação deles? Qual a experiência anterior de cada um? De qual dos sócios surgiu a idéia de abrir o negócio?

6) Quanto tempo a empresa tem de mercado?

7) A empresa possui CNPJ?

8) Quantos empregados - além dos sócios - a empresa possui hoje?

9) Você sobrevive $100 \%$ com os valores que recebe da sua empresa?

10) Você já trabalhou em alguma empresa antes? Por quanto tempo? Essa empresa era pública ou privada?

11) O que foi mais fácil para você no processo de empreender? Indique de 1 a 3 itens.

12) Qual foi a maior dificuldade que você enfrentou para empreender? Indique de 1 a 3 itens.

13) Como deve ser a empresa ideal para você? Dê uma nota de 0 a 10 para cada item a seguir:

( ) Crescimento de carreira

( ) Desenvolvimento profissional

( ) Ambiente de trabalho agradável

( ) Bons salários e benefícios

( ) Oferece cursos e treinamento 
14) Dê uma nota para cada item a seguir, de 0 a 10, no quanto você se considera:
a) Informado
b) Domina com facilidade tecnologias
c) Curioso
d) Comunicativo
e) Hiperativo
f) Ambicioso
g) Seguro para arriscar
h) Exigente
i) Criativo
j) Desejo de fazer a diferença
k) Valoriza a interação com o mundo
l) Luta pelos seus sonhos

15) Você acha que as pessoas da sua idade tem mais tendência a empreender ou trabalhar dentro de uma empresa?

16) Quais valores você considera ter?
a) Apego à família
b) Sempre ver o lado positivo das coisas
c) Metas e objetivos bem definidos
d) Desejo ético
e) Desejo de mudar o mundo
f) Preocupa-se com causas ambientais
g) Capaz de realizar diversas tarefas ao mesmo tempo
h) Ligado em tecnologia
i) Resolve tudo de maneira rápida
j) Toma ações práticas de caráter social
k) Organização
l) Coloca em prática suas idéias
m) Plenamente realizado

17) Dê uma nota para cada item a seguir, de 0 a 10, no quanto você se considera:
a) Visionário
b) Sabe tomar decisões
c) Faz a diferença
d) Sabe explorar oportunidades
e) Determinado e dinâmico
f) Dedicado
g) Otimista
h) Independente
i) Líder e formador de equipe
j) Bem relacionado
k) Organizado
I) Sabe planejar 
18) Assinale dentre as seguintes frases as que você considera como características suas:

- Realiza atividades antes de solicitado ou forçado pelas circunstâncias

- Busca novas áreas de atuação, para ampliar seu empreendimento

- Aproveita oportunidades fora do comum para começar um negócio novo.

- Age diante de dificuldades relevantes

- Insiste ou muda de estratégia com a finalidade de enfrentar desafios ou dificuldades

- Responsabiliza-se pessoalmente pelo cumprimento dos objetivos estabelecidos

- Analisa as alternativas e calcula riscos cuidadosamente

- Age para diminuir riscos ou controlar resultados

- Coloca-se em situações que implicam em desafios moderados, contanto que sejam calculados

- Age de forma a executar melhor as coisas, mais rapidamente ou mais barato

- Procede de forma a realizar coisas que satisfaçam ou excede aos padrões de excelência

- Assegura que o trabalho seja terminado a tempo e atenda aos padrões de qualidade previamente combinados.

- Sacrifica-se pessoalmente ou depende de um grande esforço para completar uma tarefa contratada

- Trabalha junto com seus empregados ou os substitui, caso seja necessário terminar uma tarefa

- Prima em manter os clientes satisfeitos e coloca em primeiro lugar a boa vontade em longo prazo, em vez de lucro em curto prazo

- Pesquisa pessoalmente informações de clientes, fornecedores e concorrentes

- Pesquisa pessoalmente sobre como fabricar um produto ou oferecer um serviço

- Solicita orientação de especialistas para obter assessoria técnica ou comercial e assim fundamentar e possibilitar a elaboração de estratégias racionais

- Fixa objetivos que Ihe proporcionem desafios e que tenham significado pessoal 
- Fixa metas em longo prazo, claras e específicas

- Fixa objetivos de curto prazo e mensuráveis

- Planeja um trabalho grande, dividindo-o em partes mais simples e com prazos definidos

- Acompanha e revisa seus planos, embasado em informações sobre o desempenho real e em novas circunstâncias

- Mantém registros financeiros e os utiliza para tomar decisões.

- Mantém suas decisões, mesmo quando outras pessoas se opõem, diante de resultados desanimadores

- Mostra-se confiante na sua própria capacidade de completar uma tarefa difícil ou de enfrentar um desafio

- Geralmente analisa as situações problema no sentido de avaliar as fraquezas e as ameaças às suas ações, buscando formas de exercer controle para eliminá-las ou amenizá-las.

- Usa de estratégias para influenciar ou persuadir os outros

- Usa de pessoas influentes para atingir seus próprios objetivos

- Age para desenvolver e manter relações comerciais

19) O que motivou você a empreender?

20) Qual foi a maior lição que você aprendeu ao longo do processo de empreender? 